\title{
Large-scale monitoring of coppice forest clearcuts by multitemporal very high resolution satellite imagery. A case study from central Italy
}

\author{
Gherardo Chirici a, ${ }^{a}$, Diego Giuliarelli ${ }^{b}$, Daniele Biscontini ${ }^{c}$, Daniela Tonti ${ }^{a}$, Walter Mattioli ${ }^{b}$, \\ Marco Marchetti ${ }^{a}$, Piermaria Corona ${ }^{\mathrm{b}}$ \\ ${ }^{\text {a }}$ ECOGEOFOR - Laboratorio di Ecologia e Geomatica Forestale, Dipartimento di Scienze e Tecnologie per l'Ambiente e il Territorio, University of Molise, Contrada Fonte Lappone, \\ I-86090 Isernia, Pesche, Italy \\ b DISAFRI - Dipartimento di Scienze per l'Ambiente Forestale e delle sue Risorse, University of Tuscia, Via San Camillo de' Lellis, I-01100, Viterbo, Italy \\ ${ }^{c}$ E-Geos spa, Roma, Italy
}

\section{A R T I C L E I N F O}

\section{Article history:}

Received 8 May 2010

Received in revised form 3 December 2010

Accepted 4 December 2010

Available online $\mathrm{xxxx}$

\section{Keywords:}

Coppice forest

Forest statistics

Clearcut mapping

SPOT5 HRG

GMES forest monitoring

Object-oriented classification

\begin{abstract}
A B S T R A C T
Reliable assessment of forest resource stock, productivity and harvesting is a commonly agreed objective of environmental monitoring programs. Distinctively, the assessment of wood harvesting has become even more relevant to evaluate the sustainability of forest management and to quantify forest carbon budget. This paper presents the development and testing of procedures for assessing forest harvesting in coppice forests by very high resolution (VHR) satellite imagery. The study area is located in central Italy over approximately $34,000 \mathrm{~km}^{2}$. A set of SPOT5 HRG multispectral images was acquired for the study years (2002-2007). Official administrative statistics of coppice clearcuts were also acquired. More than 9500 clearcuts were mapped and dated by on-screen interpretation of the SPOT5 images. In a subset of the study area various methods for semi-automatic clearcut mapping were tested by pixel- and object-oriented approaches. The following results are presented: (i) clearcut map developed by visual interpretation of the SPOT5 images resulted in high thematic (overall accuracy of 0.99) and geometric (root mean square error of clearcut boundary delineation of $5.3 \mathrm{~m}$ ) reliability; (ii) object-oriented approach achieved significantly better accuracy than pixel-based methods for semi-automatic classification of the coppice clearcuts; (iii) comparison between mapped clearcut area and official forest harvesting statistics proved a significant underestimation by the latter (65\% of the total mapped clearcut area). A sample-based procedure exploiting VHR satellite imagery is finally proposed to correct the official statistics of coppice clearcuts.
\end{abstract}

(c) 2010 Elsevier Inc. All rights reserved.

\section{Introduction}

Reliable assessment of forest resource stock, productivity and harvesting is a commonly agreed objective of environmental monitoring programs at various spatial scales (Köhl et al., 2006; Corona \& Marchetti, 2007; McRoberts \& Tomppo, 2007). Distinctively, the assessment of wood harvesting has become even more relevant to check the sustainability of forest management and to quantify forest carbon budget. For instance, the countries are asked to report this information within the framework of Forest Europe (the former Ministerial Convention on the Protection of Forests in Europe) (MCPFE, 2009), in the Montreal Process (2005), in the framework of the United Nations Framework Convention on Climate Change (UNFCCC, 2007) and the Kyoto Protocol (1997) and for the Global Forest Resource Assessment carried out by the Food and Agriculture Organization of the United Nations (FAO, 2005).

\footnotetext{
* Corresponding author. Tel.: +39 0874404138; fax: +39 0874404123.

E-mail addresses: gherardo.chirici@unimol.it (G. Chirici),
} daniele.biscontini@telespazio.it (D. Biscontini), piermaria.corona@unitus.it (P.Corona).
The forest area in Italy is $87,592 \mathrm{~km}^{2}$ ( $29 \%$ of the total land area), $42 \%$ of which is managed as coppice forest (INFC, 2007). The majority are coppices with standards, that is even-aged stands with 40-200 trees of two to three times the rotation age released at the coppicing time (Ciancio et al., 2006). Felling is carried out by clearcutting at the end of rotation (usually 15-35 years), on areas from few square hundred meters up to 10-20 ha (but most clearcuts are usually in the range 1-3 ha). Coppice is the only silvicultural system for which clearcut is allowed in Italy, with a harvesting season from November to March or April. The main product is fuelwood, and, at much less extent, polewood. In the last years the increased oil prices and the increased concern for energy renewable sources have increased fuelwood demand, for both domestic and industrial uses (Lasserre et al., 2010). Current stumpage prices are around 20-40 euros per ton, on average.

In most Italian Regions (European Union NUT2 administrative units) a simple forest owner declaration communicated to the Regional authority and to the Italian State Forest Service (Corpo Forestale dello Stato - CFS) is usually enough to start the harvesting of a coppice stand, at least for clearcut areas smaller than 3 ha. For wider clearcut areas a specific project approved by the competent 